\title{
STRUKTUR MODAL: FAKTOR PENENTU DAN PENGARUHNYA PADA NILAI PERUSAHAAN
}

\author{
Sutrisno \\ Program StudiManajemen, Fakultas Ekonomi Universitas Islam Indonesia \\ e-mail: sutrisno_uii@yahoo.com
}

\begin{abstract}
This study has two main objectives, first to determine and analyze the factors that determine capital structure, second to determine and analyze the influence of the determinants of capital structure on firm valuewith capital structure as moderating variable. Factors suggest to be determinants of capital structure consists of the firm's growth, profitability, fixed asset structure, leverage, and firm size. The population in this study is a manufacturing company that listed on the Indonesia Stock Exchange. With purposive sampling method, we find 125 companies data with 4-years observation period (2008-2011). To analyze the data, we use multiple regression that supported by e-views program. The results showed that the factors that significantly determine the capital structure are the Fixed assets structure, leverage, profitability, and firm size while the company's growth does not affect the capital structure. Meanwhile the capital structure as moderating variable, the factors significantly affect the firm's value are fixed assets structure, leverage and profitability, while the company's growth and firm size factors has no effecton firm value.
\end{abstract}

Keywords:capital structure, fixed asset structure, leverage, the firm value, firm size http://dx.doi.org/10.20885/jsb.vol20.iss1.art7

\begin{abstract}
Abstrak
Penelitian ini mempunyai dua tujuan utama yakni, pertama untuk mengetahui dan menganalisis faktor-faktor yang menentukan struktur modal, kedua untuk mengetahui dan menganalisis pengaruh faktor-faktor penentu struktur modal terhadap nilai perusahaan dengan struktur modal sebagai variabel pemoderasi. Faktor-faktor yang diduga sebagai penentu struktur modal terdiri dari pertumbuhan perusahaan, profitabilitas, struktur aktiva, leverage, dan ukuran perusahaan. Populasi dalam penelitian ini adalah perusahaan manufaktur yang terdaftar di Bursa Efek Indonesia. Dengan metode purposive sampling, diperoleh data 125 perusahaan dengan periode pengamatan 4 tahun (2008-2011). Alat analisis yang digunakan adalah regresi berganda dengan didukung program eviews. Hasil penelitian menunjukkan bahwa faktor-faktor yang secara signifikan menetukan struktur modal adalah struktur aktiva tetap, leverage, profitabilitas, dan size, sedangkan pertumbuhan perusahaan tidak mempengaruhi struktur modal. Sementara dengan struktur modal sebagi variabel pemoderasi, faktor struktur aktiva, leverage dan profitabilitas secara signifikan mempengaruhi nilai perusahaan, sedangkan faktor pertumbuhan perusahaan dan ukuran perusahaan tidak berpengaruh pada nilai perusahaan.
\end{abstract}

Kata Kunci: struktur modal, struktur aktiva, leverage, nilai perusahaan, ukuran perusahaan

\section{PENDAHULUAN}

Ada tiga keputusan kunci dan penting yang dihadapi manajer keuangan, yakni keputusan investasi, keputusan dividen dan keputusan pendanaan (Weston dan Copeland, 1986). Keputusan pendanaan merupakan keputusan untuk memilih sumber dana baik jenisnya maupun jumlahnya akan membentuk struktur modal. Manajer keuangan dituntut untuk mencari sumber dana dengan biaya yang murah dan dengan komposisi yang optimal, yakni struktur modal yang menghasilkan biaya modal atau cost of capital yang paling rendah. Biaya modal yang timbul dari keputusan pendanaan tersebut merupakan konsekwensi yang secara langsung timbul dari keputusan yang dilakukan 
manajer. Ketika manajer menggunakan dana yang berasal dari hutang, maka akan timbul biaya modal berupa bunga yang dibebankan kreditur, sedangkan jika menggunakan dana yang berasal dari pemilik (dana interal) akan timbul biaya dana berupa opportunity cost dari modal sendiri tersebut. Dengan demikian jika keputusan pendanaan tidak dilakukan dengan cermat bisa menimbulkan biaya modal yang tinggi, yang akhirnya akan berakibat pada menurunnya tingkat profitabilitas perusahaan. Brigham dan Gapenski (1996:355) mengatakan bahwa salah satu isu yang paling membingungkan dalam manajemen keuangan adalah masalah struktur modal atau perimbangan hutang dengan ekuitas.

Teori struktur modal berubah secara revolusioner dengan hadirnya artikel Modigliani dan Miller (1958) yang mematahkan teori dari pendekatan tradisional. Menurut pendekatan tradisional, nilai perusahaan akan berubah dengan cara merubah struktur modalnya, sehingga dengan cara mengubah struktur modal akan diperoleh nilai perusahaan yang optimal. MM menyatakan bahwa tidak ada hubungan antara nilai perusahaan dengan biaya modal melalui struktur modalnya. Pernyataan tersebut didukung dengan argumen arbitrase. Melalui proses arbitrase akan membuat nilai pasar perusahaan sama baiknya antara menggunakan hutang atau menggunkan modal sendiri.

Menurut Modigliani dan Miller (1958), jika ada pajak maka perubahan struktur modal menjadi relevan. Hal ini disebabkan karena bunga yang dibayarkan berfungsi sebagai pengurang pajak atau tax deductable. Perusahaan yang menggunakan hutang membayar pajak lebih sedikit dibanding dengan perusahaan yang tidak menggunakan hutang. Dengan demikian, bagi perusahaan yang menggunakan hutang bisa menghemat pajak, yang akhirnya bisa meningkatkan kesejahteraan pemilik dan meningkatkan nilai perusahaan.

Menurut MM semakin besar hutang akan semakin tinggi nilai perushaan. Tetapi pada kenyataannya dengan semakin tingginya hutang, risiko yang ditanggung perusahaan akan lebih besar, sehingga mengakibatkan probabilitas kebangkrutan semakin tinggi. Hutang yang tinggi berarti perusahaan harus menyediakan uang untuk membayar bunga dengan jumlah yang besar, sehingga kemungkinan gagal bayar juga tinggi. Jika gagal bayar kreditor bisa membangkrutkan perusahaan, oleh karena itu perlu mempertimbangkan biaya kebangkrutan. Dengan demikian, jumlah hutang yang semakin besar pada titik tertentu akan stagnan bahkan jika ditambah justru akan bisa menurunkan nilai perusahaan. Teori Modigliani dan Miller (1958) jika digabungkan dengan biaya kebangkrutan dan biaya agensi mengindikasikan adanya pergantian atau trade-off antara penghematan pajak dengan biaya kebangkrutan.

Banyak faktor yang mempengaruhi keputusan manajer dalam menentukan struktur modal perusahaan. Brigham dan Houston (2001:39) mengungkapkan beberapa faktor yang mempengaruhi struktur modal antara lain, stabilitas penjualan, struktur aktiva, leverage operasi, tingkat pertumbuhan perusahaan, profitabilitas, pajak, sikap manajemen, sikap pemberi pinjaman, kondisi pasar, dan kondisi keuangan perusahaan.Utami (2009) dalam penelitiannya menggunakan variabel ukuran perusahaan, risiko bisnis, pertumbuhan, struktur akktiva dan profitabilitas sebagai faktor penentu striktur modal. Sementara Afza dan Hussain (2011) menambahkan variabel leverage, tangibility, likuiditas, dan pajak sebagai penentu struktur modal dalam penelitiannya pada industri lintas sektor di Pakistan.

Sabir dan Malik (2012) yang meneliti sektor minyak dan gas menggunakan variabel profitabilitas, likuiditas, ukuran perusahaan, dan tangibility sebagai faktor penentu struktur modal, sementara Chowdhury dan Chowdhury (2010) menggunakan earning per share, dividend payout ratio, public owned, fixed asset turnover, long term debt to total asset, current ratio, dan salses growth sebagai penentu strukutr modal.

Dari uraian tersebut di atas dapat dirumuskan tujuan penelitian ini adalah untuk menguji faktor-faktor yang mempengaruhi terhadap struktur modal perusahaan dan nilai perusahaan. Adapun faktor-faktor yang diduga mempengaruhi struktur modal dan nilai perusahaan adalah pertumbuhan perusahaan, profitabilitas, struktur aktiva, leverage operasi, dan ukuran perusahaan.

\section{KAJIAN PUSTAKA}

\section{Nilai Perusahaan}

Semula teori perusahaan didasarkan pada asumsi bahwa maksud atau tujuan perusahaan 
adalah memaksimumkan laba sekarang atau jangka pendek. Akan tetapi, berdasarkan pengamatan perusahaan sering kali mengorbankan laba jangka pendek untuk meningkatkan laba masa depan atau jangka panjang. Karena baik keuntungan jangka pendek maupun jangka panjang sangat penting, teori perusahaan (theory of the firm) sekarang mempostulatkan bahwa maksud atau tujuan utama perusahaan adalah untuk memaksimumkan kekayaan atau nilai perusahaan (value of the firm). Hal ini dicerminkan dari nilai sekarang atas semua keuntungan perusahaan yang diharapkan di masa depan. Nilai dari perusahaan bergantung tidak hanya pada kemampuan menghasilkan arus kas, tetapi juga bergantung pada karakteristik operasional dan keuangan dari perusahaan yang diambil alih.

Tujuan utama perusahaan menurut theory of the firm adalah untuk memaksimumkan kekayaan atau nilai perusahaan (value of the firm) (Weston dan Copeland, 1986). Memaksimalkan nilai perusahaan sangat penting artinya bagi suatu perusahaan, karena dengan memaksimalkan nilai perusahaan berarti juga memaksimalkan kemakmuran pemegang saham yang merupakan tujuan utama perusahaan. Menurut Husnan (2000) nilai perusahaan merupakan harga yang bersedia dibayar oleh calon pembeli apabila perusahaan tersebut dijual. Sedangkan menurut Keown (2002) nilai perusahaan merupakan nilai pasar atas surat berharga hutang dan ekuitas perusahaan yang beredar.

Menurut Brigham dan Houston (2001) terdapat beberapa pendekatan analisis rasio dalam penilaian market value, terdiri dari pendekatan price earning ratio (PER), price book value ratio (PBVR), market book value ratio (MBVR), deviden yield ratio, dan deviden payout ratio (DPR). Dalam penelitian ini nilai perusahaan diukur dengan PBVR.

Rasio harga saham terhadap nilai buku perusahaan atau price book value (PBV), menunjukkan tingkat kemampuan perusahaan menciptakan nilai relatif terhadap jumlah modal yang diinvestasikan. PBV yang tinggi mencerminkan harga saham yang tinggi dibandingkan nilai buku perlembar saham. Semakin tinggi harga saham, semakin berhasil perusahaan menciptakan nilai bagi pemegang saham. Keberhasilan perusahaan menciptakan nilai tersebut tentunya memberikan harapan kepada pemegang saham berupa keuntungan yang lebih besar pula (Sartono, 2001).

\section{Teori Struktur Modal}

Perkembangan teori struktur modal modern dimulai pada tahun 1958, ketika Modigliani dan Miller (selanjutnya disebut MM) menerbitkan suatu artikel keuangan paling berpengaruh yang pernah ditulis. MM membuktikan, dengan sekumpulan asumsi yang sangat membatasi, bahwa nilai sebuah perusahaan tidak terpengaruh oleh struktur modalnya. Atau dengan kata lain, hasil yang diperoleh MM menunjukkan bahwa bagaimana cara sebuah perusahaan akan mendanai operasinya tidak akan berarti apa-apa, sehingga struktur modal adalah suatu hal yang tidak relevan. Hasil karya MM menandai awal penelitian struktur modal modern, dengan penelitian selanjutnya berfokus pada melonggarkan asumsi-asumsi MM guna mengembangkan sutau teori struktur modal yang lebih realistis.

\section{Pengaruh Perpajakan}

MM menerbitkan makalah lanjutan pada tahun 1963 di mana di dalamnya mereka melonggarkan asumsi tidak adanya pajak perusahaan. Peraturan perpajakan memperbolehkan perusahaan untuk mengurangkan pembayaran bunga sebagai suatu beban, akan tetapi pembayaran deviden kepada pemegang saham tidak dapat menjadi pengurangan pajak. Perbedaan perlakuan ini mendorong perusahaan menggunakan hutang dalam struktur modalnya. Tentu MM mendemontrasikan bahwa jika seluruh asumsi mereka lain yang tetap berlaku, perlakuan yang berbeda iniakan mengarah pada terjadinya suatu situasi dimana perusahaan didanai100 persen oleh hutang.

\section{Pengaruh Potensi Terjadinya Kebangkrutan}

Hasil irelevansi MM juga tergantung pada asumsi bahwa perusahaan tidakakan bangkrut, sehingga tidak akan ada biaya kebangkrutan. Namun, kebangkrutan pada praktiknya terjadi, dalam hal ini sangat mahal biayanya. Perusahaan yang bangkrut akan memiliki beban akuntansi dan hukum yang sangat tinggi, dan juga mengalami kesulitan untuk mempertahankan pelanggan, pemasok dan karyawannya. Masalah-masalah yang berhubungan dengan 
kebangkrutan kemungkinan besar akan timbul ketika sebuah perusahaan memasukkan lebih banyak hutang dalamstruktur modalnya. Karena itu, biaya kebangkrutan menahan perusahaanmendorong penggunaan hutangnya hingga ke tingkat yang berlebihan.

\section{Teori Trade-off}

Fakta bahwa bunga adalah beban pengurangan pajak menjadikan hutanglebih murah daripada saham biasa atau saham preferen. Akibatnya, secara tidak langsung pemeritah akan membayarkan sebagian biaya dari modal hutang, atau dengan cara lain, hutang memberikan manfaat perlindungan pajak. Semakin banyak perusahaan menggunakan hutang, maka semakin tinggi nilai dan harga sahamnya, menurut asumsi tulisan Moddigliani-Miller dengan pajak, harga saham sebuah perusahaan akan mencapai nilaimaksimal jika perusahaan sepenuhnya menggunakan hutang 100 persen. Dalam dunia nyata, perusahaan jarang menggunakan hutang 100 persen. Alasan utama perusahaan membatasi penggunaan hutang adalah untuk menjaga biaya-biaya yang berhubungan dengan kebangkrutan tetap rendah.

\section{Teori Signaling}

MM berasumsi bahwa investor memiliki informasi yang sama tentang prospek sebuah perusahaan seperti para manajernya, hal ini disebut informasi simetris (symmetric information). Namun kenyataanya, para manajer seringkali memiliki informasi yang lebih daripada pihak luar. Hal ini disebut informasi asimetris (asymmetric information), dan memiliki pengaruh yang penting pada struktur modal yang optimal.

\section{Teori keagenan}

Perusahaan dapat mengurangi arus kas yang berlebihan dengan beragamcara. Salah satunya adalah dengan menyalurkan kembali kepada pemegang saham melalui deviden yang lebih tinggi atau pembelian kembali saham. Alternatif yang lain adalah untuk mengubah struktur modal ke arah hutang dengan harapan adanya persyaratan penutupan hutang yang lebih tinggi akan memaksa manajer untuk lebih disiplin. Jika hutang tidak tertutupi seperti yang diharuskan, perusahaan akan terpaksa dinyatakan bangkrut. Pembelian melalui hutang (laverage buyout-LBO)adalah satu cara untuk mengurangi kelebihan arus kas. Dalam suatu LBO hutang digunakan untuk mendanai pembelian saham sebuah perusahaan,dimana selanjutnya akan dimiliki secara pribadi.

Struktur modal adalah perimbangan atau perbandingan antara jumlah hutang jangka panjang dengan modal sendiri. Oleh karena itu, struktur modal diukur dengan debt to equity ratio (DER). DER merupakan rasio yang digunakan untuk mengukur tingkat leverage (penggunaan hutang) terhadap total shareholder's equity yang dimiliki perusahaan.

\section{Faktor-faktor yang memperngaruhi Struktur Modal}

Menurut Weston dan Copeland (1986), variabel-variabel yang mempengaruhi struktur modal adalah: tingkat pertumbuhan penjualan, stabilitas arus kas, karakteristik industri, struktur aktiva, sikap manajemen, dan sikap pemberi pinjaman. Sedangkan menurut Brigham dan Gapenski (1996:174), mengatakan bahwa variabel-variabel yang mempengaruhi struktur modal adalah: stabilitas penjualan, struktur aktiva, leverage operasi, tingkat pertumbuhan, profitabilitas, pajak, pengendalian, sikap manajemen, sikap pemberi pinjaman, kondisi pasar, kondisi internal perusahaan, dan fleksibilitas keuangan.

\section{Pengembangan Hipotesis}

Seperti telah diuraikan diawal bahwa Modigliani dan Miller (1958) jika perusahaan menggunakan hutang maka nilai perusahaan bisa ditingkatkan dengan menambah hutang. Namun demikian jika hutang terus ditambah menyebabkan risiko perusahaan tinggi, sehingga memungkinkan timbulnya biaya kebangkrutan. Dengan demikian akan terjadi tarde-off dengan biaya kebangkrutan jika hutang terus ditambah. Bahkan Myers (1984) dengan pecking order theory-nya mengungkapkan bahwa dalam pemenuhan sumber dana, perusahaan mempunyai urutan dari yang paling murah yakni laba ditahan, kemudian sumber dana eksternal (laba ditahan dan penysustan), baru jika masih kurang mencari sumber dana internal yang berasal dari emisi saham.

Mas'ud (2008) menemukan bahwa struktur modal yang diproksikan dengan cost of 
financial distrution mempunya pengaruh yang signifikan terhadap nilai perusahaan. Temuan Kesuma (2010) juga mendukung bahwa strktur modal berpengaruh padanilai perusahaan yang diproksikan dengan harga saham. Struktur modal yang optimal akan meningkatkan kinerja perusahaan, seperti yang ditemukan oleh Maxwell dan Kehinde (2012). dalam penelitiannya di Nigeria. Dari uraian di atas dapat dibuat hipotesis sebagai berikut:

$\mathrm{H}_{1}$ : Struktur modal berpengaruh secara signifikan terhadap nilai perusahaan

Pertumbuhan perusahaan mengukur seberapa baik perusahaan dalam mempertahankan posisi ekonominya, baik dalam industrinya maupun dalam kegiatan ekonomi secara keseluruhan (Weston dan Copeland, 1986). Pertumbuhan perusahaan menunjukkan kemampuan perusahaan untuk dapat bertahan dalam kondisi persaingan. Pertumbuhan perusahaan dapat diukur dengan dua indikator (1) pertumbuhan penjulan dan (2) pertumbuhan aset. Pertumbuhan penjualan yang lebih tinggi dibandingkan dengan kenaikan biaya akan mengakibatkan kenaikan laba perusahaan. Jumlah laba yang diperoleh secara teratur serta kecenderungan atau trend keuntungan yang meningkat merupakan suatu faktor yang sangat menentukan perusahaan untuk tetap survive. Sementara perusahaan dengan rasio pertumbuhan penjualan negatif berpotensi besar mengalami penurunan laba sehingga apabila manajemen tidak segera mengambil tindakan perbaikan, perusahaan dimungkinkan tidak akan dapat mempertahankan kelangsungan hidupnya.

Gill, Biger, Pai, dan Bhutani (2009), Akhtar, Husnain, dan Mukhtar (2011), dan Ilyas (2010) menemukan pengaruh yang signifikan antara pertumbuhan perusahaan dengan strukur modal. Demikan pula dengan Utami (2009), Margaretha dan Ramadhan (2010), Priyono (2010) dan Chowdhury dan Chowdhury (2010) menemukan hubungan yang signifikan antara pertumbuhan dengan struktur modal.

Sedangkan pertumbuhan aset menunjukkan menunjukkan tingkat perkembangan aset dari periode sebelumnya. Brigham dan gapenski (1996) mengungkapkan bahwa perusahaan dengan tingkat pertumbuhan yang cepat banyak mengandalkan sumber dana eks- ternal. Dengan demikian pertumbuhan perusahaan akan mendorong peningkatan struktur modal. Mas'ud (2008) juga menemukan hubungan yang positif ntara pertumbuhan dengan struktur modal. Teori signaling pada umumnya memprediksikan bahwa perusahaan dengan pertumbuhan cerah akan menggunakan hutang untuk membiayai investasinya. Oleh karena itu bisa dibuat hipotesis sebagai berikut:

$\mathrm{H}_{2 \mathrm{a}}$ : Pertumbuhan berpengaruh pada struktur modal

$\mathrm{H}_{2 \mathrm{~b}}$ : Pertumbuhan berpengaruh pada nilai perusahaan melalui struktur modal sebagai variabel pemoderasi

Profitabilitas juga merupakan variabel yang mempengaruhi struktur modal. Dalam penelitian ini kemampulabaan diwakili oleh Return On Assets (ROA), yaitu dengan membandingkan laba bersih dengan total aktiva perusahaan. Menurut Weston dan Copeland (1986), perusahaan dengan tingkat return on assets yang tinggi, umumnya menggunakan hutang dalam jumlah yang relatif sedikit. Hal ini disebabkan dengan return on assets yang tinggi tersebut, memungkinkan bagi perusahaan menambah permodalan dengan laba ditahan saja. Akan tetapi tidak itu saja, asumsi yang lain mengatakan dengan return on assets yang tinggi, berarti bahwa laba bersih yang dimiliki perusahaan tinggi, maka apabila perusahaan menggunakan hutang yang besar tidak akan berpengaruh pada struktur modal, karena kemampuan perusahaan dalam membayar bunga tetap juga tinggi. Tingkat pengembalian yang tinggi memungkinkan untuk membiayai sebagian besar kebutuhan pendanaan dengan dana yang dihasilkan secara internal.Myers (1984) dengan pecking order theory-nya mengungkapkan bahwa ada pengaruh negatif antara profitabilitas dengan strktur modal. Walapun ada yang menemukan hal yang sebaliknya seperti Gill et.al (2009) yang menemukan hubungan yang positif antara profitabilitas dengan struktur modal.

Profitabilitas yang tinggi merupakan harapan para investor dan pemegang saham, sebab dengan tingginya profitabilitas akan mampu meningkatkan harga saham sebagai ukuran nilai perusahaan. Mas'ud (2008) menemukan pengaruh yang positif antara profitabilitas dengan nilai perusahaan.Oleh karena itu hiptesis ketiga adalah: 
$\mathrm{H}_{3 \mathrm{a}}$ : Profitabilitas berpengaruh pada struktur modal.

$\mathrm{H}_{3 \mathrm{~b}}$ : Profitabilitas berpengaruh pada nilai perusahaan melalui struktur modal sebagai variabel pemoderasi.

Operating leverage timbul pada saat perusahaan menggunakan aktiva yang memiliki biaya-biaya operasi tetap. Leverage operasi mencerminkan pengaruh besarnya biaya tetap terhadap laba perusahaan (Weston dan Copeland, 1986). Dalam hal ini perubahan biaya tetap yang kecil akan mengakibatkan perubahan laba yang besar. Dengan penggunaan biaya tetap yang rendah akan menghasilkan laba yang besar, laba yang besar ini memungkinkan perusahaan. untuk membiayai sebagaian besar kebutuhan pendanaan dengan dana yang dihasilkan secara internal. Semakin tinggi laba yang diperoleh, berarti semakin rendah kebutuhan dana eksternal (hutang), sehingga semakin rendah pula struktur modalnya. Afza dan Hussain (2011) dan Choudory et.al (2010) menggunakan variabel leverage sebagai faktor yang mempengaruhi struktur modal. Demikian pula dengan Kesuma (2010) dan Jono dan Lina (2010) yang melakukan penelitian di Bursa Efek Indonesia, juga menggunakan leverage sebagai faktor yang mempengaruhi struktur modal. Sehingga hipotesis keempat yang kami buat adalah:

$\mathrm{H}_{4 \mathrm{a}}$ : Operating Leverage berpengaruh pada struktur modal

$\mathrm{H}_{4 \mathrm{~b}}$ : Operating Leverage berpengaruh pada nilai perusahaan melalui struktur modal sebagai variabel pemoderasi

Struktur aktiva diklasifikasikan menjadi dua bagian utama, yang pertama aktiva lancar (meliputi kas, investasi jangka pendek, piutang wesel, piutang dagang, persediaan, piutang penghasilan, serta perskot). Kedua aktiva tidak lancar (meliputi: investasi jangka panjang, aktiva tetap, aktiva tetap tidak berujud). Kebanyakan dari perusahaan industri yang sebagian besar modalnya tertanam dalam aktiva tetap, biasanya mengutamakan pemenuhan kebutuhan untuk modalnya diambil dari modal yang permanent atau modal sendiri. Sedangkan modal asing hanyamn digunakan sebagai pelengkap. Hal ini dapat dihubungkan dengan adanya struktur financial conservative, dimana modal sendiri paling sedikit dapat menutupi jumlah aktiva tetap, ditambah aktiva lainnya. Sabir dan Malik (2012) dan Ilyas (2010) menggunkan struktur aktiva sebagai variabel yang mempengaruhi struktur modal, demikian juga dengan Hossain dan Ali (2012) yang melakukan penelitian di Malaysia.

$\mathrm{H}_{5 \mathrm{a}}$ : Struktur aktiva berpengaruh pada struktur modal.

$\mathrm{H}_{5 \mathrm{~b}}$ : Struktur Aktiva berpengaruh pada nilai perusahaan melalui struktur modal sebagai variabel pemoderasi.

Salah satu tolok ukur yang menunjukkan besar kecilnya perusahaan adalah besarnya aktiva dari perusahaan tersebut. Perusahaan yang memiliki total aktiva besar menunjukkan bahwa perusahaan tersebut telah mencapai tahap kedewasaan dimana dalam tahap ini arus kas perusahaan sudah positif dan dianggap memiliki prospek yang baik dalam jangka waktu yang relatif lama, selain itu juga mencerminkan bahwa perusahaan relatif lebih stabil dan lebih mampu menghasilkan laba dibanding perusahaan dengan total asset yang kecil (Gill et al, 2009 )

Aktiva merupakan tolok ukur besaran atau skala suatu perusahaan. Biasanya perusahaan besar mempunyai aktiva yang besar pula nilainya. Secara teoritis perusahaan yang lebih besar mempunyai kepastian (certainty) yang lebih besar daripada perusahaan kecil sehingga akan mengurangi tingkat ketidakpastian mengenai prospek perusahaan ke depan. Hal tersebut dapat membantu investor memprediksi risiko yang mungkin terjadi jika ia berinvestasi pada perusahaan itu. Mas'ud (2008) dan Ilyas menggunakan ukuran perusahaan sebagai salah satu faktor yang mempengaruhi struktur modal, demikian pula dengan Afza dan Hussain (2011) dan Gill et.al (2009).

$\mathrm{H}_{6 \mathrm{a}}$ : Ukuran perusahaan berpengaruh pada struktur modal

$\mathrm{H}_{6 \mathrm{~b}}$ : Ukuran perusahaan berpengaruh pada nilai perusahaan melalui struktur modal sebagai variabel pemoderasi

\section{METODE PENELITIAN}

\section{Populasi dan sampel}

Pada penelitian ini populasinya adalah semua perusahaan manufaktur yang tercatat di Bursa Efek Indonesia dari tahun 2008sampai tahun 2011. Sedangkan sampel yang diambil sebagai representasi populasinya adalah semua sektor 
yang ada di bursa. Sampel yang akan diambil sebanykak 125 perusahaan, yang pengambilan sampelnya menggunakan metode acak sederhana dengan mempertimbangkan keterwakilan masing-masing sektor industri.

\section{Variabel Penelitian}

Variabel penelitian ini terdiri dari dua yakni variabel dependen dan variabel independen dengan proksi dan pengukuran variabelnya sebagai disajikan pada tabel 1 .

\section{Alat analisis}

Alat analisis yang digunakan dalam penelitian ini adalah model Analisis Regresi Berganda (Multiple Regression Analysis). Analisis regresi berganda ini digunakan dalam rangka untuk mengetahui (1) faktor penentu struktur modal, (2) faktor yang mempengaruhi nilai perusahaan dengan struktur modal sebagai variabel pemoderasi. Persamaan regresinya adalah sebagai berikut:

$$
\begin{aligned}
\mathrm{CS}= & \propto+\beta 1 \mathrm{FGr}+\beta 2 \mathrm{Prof}+\beta 3 \mathrm{Lev}+\beta 4 \mathrm{FAR} \\
& +\beta 5 \mathrm{Sz}+\varepsilon \mathrm{i}
\end{aligned}
$$

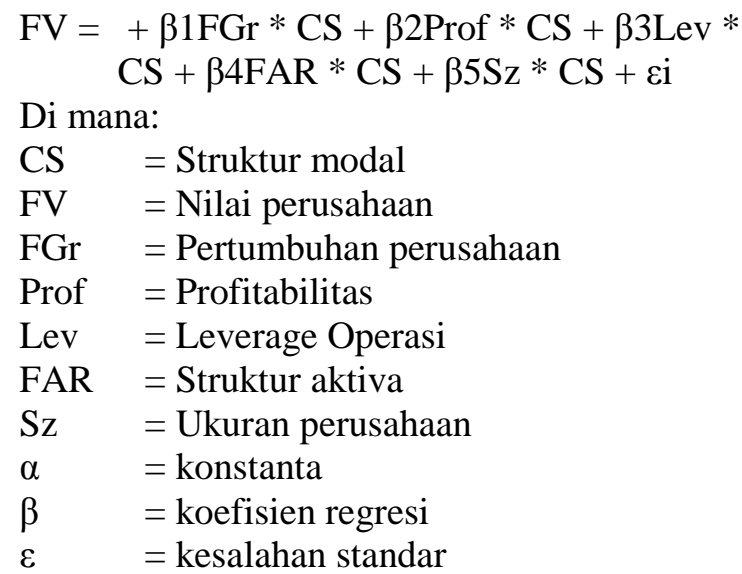

\section{HASIL ANALISIS}

\section{Struktur Modal dan Faktor Penentu}

Dalam penelitian ini, peneliti mengambil beberapa variabel yang diduga mempengaruhi struktur modal. Variabel tersebut antara lain profitabilitas, pertumbuhan perusahaan, struktur aktiva, leverage operasi, dan ukuran perusahaan. Setelah dilakukan analisis statistik dengan menggunakan regresi berganda, diperoleh hasil regresi sebagaimana disajikan pada tabel 2 .

Tabel 1: Proksi dan Pengukuran Variabel

\begin{tabular}{llll}
\hline No & Variabel & Proksi & Pengukuran \\
\hline 1 & Nilai Perusahaan & MBVR & Harga saham/Nilai buku perlembar saham \\
2 & Struktur Modal & LTDTA & Hutang jangka panjang/Total aset \\
3 & Pertumuhan Perusahaan & Fgr & $\left(\mathrm{TA}_{\mathrm{t}}-\mathrm{TA}_{\mathrm{t}-1}\right) / \mathrm{TA} \mathrm{A}_{\mathrm{t}} \rightarrow \mathrm{TA}=$ Total Aset \\
4 & Profitabilitas & ROE & Laba Setelah Pajak/Modal sendiri \\
5 & Leverage Operasi & LEV & $\%$ perubahan EBIT/\% perubahan Sales \\
6 & Struktur Aktiva & FAS & Aktiva tetap/Total aktiva \\
7 & Ukuran Perusahaan & Sz & Logaritma Total Asset \\
\hline
\end{tabular}

Tabel 2:HasilUjiHiptesis

\begin{tabular}{lcccc}
\hline \multicolumn{1}{c}{ Variabel } & Koefisien & StdErroe & t-statistic & Prob \\
\hline C & -0.182478 & 0.087487 & -2.085776 & 0.0382 \\
FGR & -0.007308 & 0.031260 & -0.233786 & 0.8154 \\
FAR & 0.338810 & 0.046810 & 7.237986 & 0.0000 \\
LEV & -0.000132 & $9.54 \mathrm{E}-05$ & -1.387744 & 0.0466 \\
ROE & -0.003845 & 0.001690 & -2.274845 & 0.0239 \\
SIZE & 0.014853 & 0.006816 & 2.179035 & 0.0304 \\
\hline
\end{tabular}

Variable dependend: LTDA

Tabel 3: HasilUjiHiptesis

\begin{tabular}{lcccc}
\hline Variabel & Koefisien & StdErroe & t-statistic & Prob \\
\hline C & 13.16219 & 3.600364 & 3.655795 & 0.0003 \\
FGR & 11.92912 & 65.29211 & 0.182704 & 0.8552 \\
FAR & 32.21325 & 52.33060 & 0.615572 & 0.5388 \\
LEV & 0.512358 & 0.157816 & 3.246562 & 0.0014 \\
ROE & -11.09091 & 5.660612 & -1.959312 & 0.0414 \\
SIZE & -2.751544 & 3.548593 & -0.775390 & 0.0439 \\
\hline
\end{tabular}

Variable dependend: MBVR 
Dari tabel 2 dapat disimpulkan bahwa dari lima variabel yang diduga mempengaruhi struktur modal, ternyata hanya pertubuhuan perusahaan yang pengaruhnya signifikan tidak signifikan terhadap struktur modal, yang ditunjukkan dengan nilai probalitasnya sebesar $81,54 \%$ jauh lebih besar dibanding dengan taraf signifikansinya sebesar 5\%. Sedangkan struktur aktiva (FAR) mempunyai pengaruh yang signifikan yang ditunjukkan dengan nilai probabilitas sebesar 0.000 lebih kecil dibanding dengan taraf signifikansinya. Leverage operasi juga mempengaruhi struktur modal secara signifikan dengan nilai probabilitas sebesar 4,77\% lebih kecil dibanding dengan taraf signifikansinya. Leverage operasi mempunyai pengaruh negatif terhadap struktur modal, artinya jika leverage operasi meningkat akan menurunkan struktur modalnya. Sementara profitabilitas mempunyai nilai probabalitas statistik sebesar 0.0239 lebih kecil dibanding taraf signifikansinya 5\%, artinya profitabilitas juga mempengaruhi struktur modal secara signifikan terhadap struktur modal. Profitabilitas juga mempunyai pengaruh yang negatif terhadap struktur modal. Sedangkan ukuran perusahaan (size) juga mempunyai pengaruh positif dan signifikan terhadap struktur modal.

\section{Nilai perusahaandan struktur modal sebagai variabel moderator}

Struktur modal secara parsial mempengrauhi nilai perusahaan, sementara ada faktor-faktor penentu struktur modal yang secara statistik mempengaruhinya. Penulis ingin menguji apakah faktor-faktor penentu struktur modal tersebut akan mempengaruhi nilai perusahaan dengan struktur modal sebagai variabel pemoderasi. Tabel 3. merupakan hasil olah statistik pengaruh masing-masing variabel dengan struktur modal sebagai pemoderasi.

Tabel 3 menunjukkan uji $F$ untuk menguji secara serentak antara variabel-variabel pengaruh dan yang dipengaruhi, menunjukkan -faktor-faktor penentu struktur modal dengan struktur modal sebagai pemoderasisecara signifikan mempengaruhi nilai perusahaan yang ditunjukkan dengan nilai probabilitas f-statistiknya sebesar 0.011008 lebih kecil dibanding taraf signifikansinya 0.05 .

Secara parsial, variabel pertumbuhan perusahaan yang di moderatori struktur modal tidak mempengaruhi nilai perusahaan, yang bisa dilihat dari nilai probablitas t-statistiknya sebesar 0.5388 lebih besar 0.05. Demikain pula dengan variabel struktur aktiva (FAR) juga secara statistik tidak mempengaruhi nilai perusahaan jika menggunakan struktur modal sebagai variabel pemoderasi yang ditunjukkan dengan nilai t-statistiknya 0.8552 lebih besar dibanding taraf signifikansinya yang 0.05 .

Sementara variabel leverage operasi melalui struktur modal sebagai variabel pemoderasi menghasilkan nilai t-statistik 0.0014 lebih kecil dibanding dengan taraf signifikansi 0.05 . Variabel profitabilitas (ROE) melalui struktur modal sebagai variabel moderator juga berpengaruh pada nilai perusahaan karena menghasilkan nilai probablitas t-statistik sebesar 0.0414. Demikian juga dengan variabel ukuran perusahaan dengan struktur modal sebagai variabel moderator menunjukkan nilai t-statistik sebesar 0.0439 lebih kecil dibanding taraf signifikansinya 0.05 , artinya ada pengaruhnya secara signifikan terhadap nilai perusahaan.

\section{PEMBAHASAN}

Struktur modal secara signifikan mempengaruhi nilai perusahaan, namun pengaruhnya bersifat negatif artinya semakin besar struktur modal akan menurunkan nilai perusahaan. Hal ini bisa terjadi, karena dengan semakin besarnya struktur modal akan semakin banyak menanggung beban bunga. Hasil ini memang bertentangan dengan temuan Modiglini and Miller (1963) yang mengungkapkan bahwa dengan adanya pajak, semakin besar jumlah hutang akan semakin meningkatkan nilai perusahaan. Namun temuan ini didukung oleh hasil penelitian Mas'ud (2008) dan Kesuma (2010) yang menemukan pengaruh yang signifikan antara struktur modal dan nilai perusahaan. Demikian pula dengan Gupta, Srivastava, dan Sharma (2007) yang meneliti di pasar modal India, juga menemukan pengaruh yang signifikan dan negatif antara struktur modal dengan nilai perusahaan. Maxwell dan Kehinde (2012) dan Mesulis (1983) menemukan ada pengaruh yang signifikan antara struktur modal dengan nilai perusahaan.

Pertumbuhan perusahaan yang diduga mempunyai pengaruh yang signifikan, ternyata dalam penelitian ini menemukan pengaruh 
yang tidak signifikan. Hal ini dapat dimengerti sebab perusahaan yang pertumbuhannya tinggi membutuhkan dana ekuitas yang besar (Myers dan Majluf, 1984). Namun Mas'ud (2008) menemukan ada pengaruh yang positif dan signifikan antara pertumubuhan dengan struktur modal. Pertumbuhan perusahaan juga tidak signifikan mempengaruhi nilai perusahaan melaui struktur modal sebagai variabel moderasi. Temuan ini sesuai dengan hasil penelitian Chudory et.al (2010) yang menemukan pengaruh yang tidak signifikan antara pertumbuhan perusahaan dengan struktur modal. Sementara Burhanuddin (2009) menemukan pengaruh positif antara pertumbuhan perusahaan dengan nilai perusahaan yang diproksikan dengan harga saham.

Variabel struktur aktiva yang diproksikan dengan fixed assets ratio (FAR) secara signifikan mempengaruhi struktur modal. Dengan semakin tingginya kebutuhan aktiva tetap untuk menjalankan operasional perusahaan dibutuhkan dana yang besar, sehingga jika dana dipenuhi dari hutang akan meningkatkan struktur modal. Mas'ud (2008), Jono dan Lina (2010) juga menemukan pengaruh positif struktur aktiva terhadap struktur modal. Temuan ini didukung hasil penelitian Utami (2009), Margaretha dan Ramadhan (2010), dan Hossain dan Ali (2012). Sedangkan pengaruh struktur aktiva terhadap nilai perusahaan yang dimoderatori struktur modal tidak signifikan, artinya semakin besar aktiva tetap perusahaan tidak mempengaruhi besarnya nilai perusahaan. Hasil ini sejalan dengan temuan Kesuma (2010) dan Gill et.al (2011) yang menemukan pengaruh tidak signifikan antara struktur aktiva dengan nilai perusahaan. Hasil yang sama ditemukan oleh Sabir dan malik (2012). Namun Akhter et.al (2011), Mas'ud (2008), dan Utami (2009) menemukan ada pengaruh yang signifikan antara struktur aktiva dengan nilai perusahaan. Demikian pula dengan Hossain dan Ali (2012) menemukan pengaruh yang signifikan.

Dari variabel leverage operasi ditemukan ada pengaruh yang signifikan terhadap struktur modal. Hasil ini mendukung hasil penelitian Barral (2004) yang melakukan penelitian di Nepal. Demikian juga dengan Kesuma (2010) yang meneliti perusahaan publik di Indonesia menemukan hubungan yang signifikan. Namun beberapa peneliti menemukan hal yang sebaliknya, seperti Chowdhory et.al (2010) dan Priyono (2010) menemukan pengaruh yang tidak signifikan antara leverage operasi dengan struktur modal. Sementara jika dimoderatori strktur modal, pengaruh leverage operasi terhadap nilai perusahaan terbukti secara statistik signifikan. Kesuma (2010) juga menemukan hal yang sama, sementara Chudory et. al., (2010) menemukan hal yang bertentangan yakni tidak ada pengaruh yang signifikan.

Profitabilitas yang diproksikan dengan returm on equity (ROE) mempunyai pengaruh yang posisitf dan signifikan terhadap struktur modal, artinya dengan tingkat keuntungan yang tinggi semakin meningkatkan struktur modal. Hasil penelitian ini mendukung penemuan Hossain dan Ali (2012), Barral (2004), Margaretha dan Ramadhan (2010), Gill (2009), dan Afza dan Hussain (2011) yang juga menemukan pengaruh positif dan signifikan antara profitabilitas dengan struktur modal. Akhtar et.al (2011) juga menemukan pengaruh yang signifikan antara profitabilitas dengan struktur modal, namun pengaruhnya negatif. Ini memungkinkan jika perusahaan dalam kebijakan struktur modalnya menggunakan pecking order thoeri, dimana dengan semakin tingginya profitabilitas maka manajemen lebih banyak menggunakan laba tersebut untuk membelanjai kebutuhan tambahan dananya. Namun demikian ada beberapa peneliti seperti Mas'ud (2008), Kesuma (2010) dan Mesulis (1983) menemukan hasil berbeda yakni profitabilitas pengaruhnya tidak signifikan terhadap struktur modal.Dalam kaitannya dengan nilai perusahaan, diperoleh hasil bahwa profitabilitas dengan struktur modal sebagai moderator secara signifikan mempengaruhi nila perusahaan, artinya semakin tinggi profitabilitas perusahaan semakin tinggi nilai perusahaan. Penelitian ini mendukung temua Mesulis (1983), demikian juga Mas'ud (2008) dan Kesuma (2010) yang meneliti perusahaan pasar modal Indonesia menemukan pengaruh yang signifikan antara profitabilitas dengan nilai perusahaan.

Ukuran perusahaan (size) yang diukur dengan logaritma natural dari total aset, banyak digunakan sebagai variabel kontrol dalam penelitian. Dalam penelitian diperoleh pengaruh yang signifikan antara ukuran perusahaan dengan struktur modal. Besar kecilnya perusa- 
haan sangat berpengaruh pada keputusan penggunaan hutang dalam struktur modal, terutama kemampuan memperoleh pinjaman (Mas'ud, 2008). Margaretha dan Ramadhan (2010), Afza dan Hussain (2011), dan Stefani dan Handayani (2011) juga menemukan pengaruh yang positif dan signifikan antara ukuran perusahaan dengan struktur modal. Namun Akhar, et.al (2011) menemukan pengaruh signifikan tetapi negatif antara size dengan struktur modal. Dalam hubungannya dengan nilai perusahaan, dengan dimoderatori struktur modal, ditemukan hubungan yang signifikan dan positif antara ukuran perusahaan dengan nila perusahaan. Hal ini menunjukkan perusahaan besar diyakni lebih bisa memberikan jaminan peningkatan harga saham. Mas'ud (2008) dan Mesulis (1983) juga menemukan pengaruh yang positif antara ukuran perusahaan dengan nilai perusahaan.

\section{PENUTUP}

Faktor-faktor yang secara signifikan menentukan besarnya struktur modal adalah tingkat profitabilitas, leverage operasi, struktur aktiva, dan ukuran perusahaan, yang ditandai dengan nilai probablitas t-statistiknya yang lebih rendah dibanding dengan taraf signifikansinya. Sementara faktor yang secara statistik pengaruhnya tidak signifikan adalah variabel pertumbuhan perusahaan. Dari faktor yang secara signifikan mempengaruhi struktur modal, faktor leverage dan profitabilitas mempunyai pengaruh yang negatif terhadap struktur modal, artinya jika leverage operasi dan profitabiilitas bertambah maka struktur modalnya justru berkurang.

Variabel-variabel yang diduga mempengaruhi besarnya nlai perusahaan dengan struktur modal sebagai moderator, ternyata struktur modal mempunyai pengaruh negatif dan signifikan. Ini menunjukkan bahwa semakin banyak hutang perusahaan (struktur modal semakin tinggi) akan menurukan tingkat keuntungan atau profitabilitas. Variabel yang secara signifikan mempengaruhi nilai perusahaan melalui struktur modal sebagai variabel moderasi adalah leverage operasi, tingkat profitabilitas, dan ukuran perusahaan. Sementara variabel pertumbuhan perusahaan dan struktur aktiva pengaruhnya secara statistik tidak signifikan.

\section{DAFTAR PUSTAKA}

Afza, T., dan Hussain, A. (2011). Determinants of capital structure across selected manufacturing sectors of Pakistan. International Journal of Humanities and Social Science.1(12). 254262.

Akhtar, P., Husnain, M., dan Mukhtar, M.A., 2011. The determinants of capital structure: a case from Pakistasn textile sector. Proceeding: International Conference on Business and Management.

Baral, K. J. 2004. Determinants of capital structure: A case study of listed companies of Nepal. Journal of Nepalese Business Studies. 1(1). 1-13.

Brigham, Uegene F., dan Louis C. Gapensi. 1996. Intermediate Financial Management, $10^{\text {th }}$ ed. Tokyo: The Dryden Press Company.

Burhanudin. 2009. Pengaruh earning per share, pertumbuhan perusahaan, dan suku bunga terhadap harga saham. Jurnal Hipotesis. 1(2). 83-94.

Chowdhury, A., dan Chowdhury, S.P., 2010. Impact of capital structure on firm's value: evidence from Bangladesh. Peer-Reviewed And Open Access Journal.3(3). 11-122.

Gill, A., Biger, N., Pai, C., dan Bhutani, S. 2009. The determinants of capital structure in the service industry: evidence from United States. The Open Business Journal, 2, 48-53.

Gupta, P., Srivastava, A., dan Sharma, D. 2007. capital structure and financial performance: Evidence from India. Gautam Buddin University. Greater Noida. India.

Hossain, F., dan Ali, A. 2012. Impact of firm specific factors on capital structure decision: an empirical study of Bangladeshi companies.International Journal of Business Research and Management. 3(4). 163-182.

Ilyas, J. 2008. The determinants of capital structure: Analysis of non-financial firms listed in Karachi stock exchange 
in Pakistan. Journal of Managerial Sciences. 2(2). 279-307.

Jono dan Lina. 2010. Faktor-faktor yang mempengaruhi struktur modal. Jurnal Bisnis dan Akuntansi.12(2). 81-96.

Keown, A. J. 2002. Financial Management. $9^{\text {th }}$ edition. New Jersey. Pearson Education. Inc.

Kesuma, Ali.2010. Analisis faktor yang mempengaruhi struktur modal serta pengaruhnya terhadap harga saham perusahaan real estate yang go public di Bursa Efek Indonesia.Working Paper. Universitas darwan Ali, Kalteng.

Margaretha, F., dan Ramadhan, A. R. 2010. Faktor-faktor yang mempengaruhi struktur modal pada industri manufaktur di Bursa Efek Indonesia. Jurnal Bisnis dan Akuntansi. 12(2). 119-130.

Mesulis, R. W. 1983. The impact of capital structure change on firm value: Some estimates. Journal of Finance. 38 (1). 107-126.

Mas'ud, M.2008. Analisis faktor-faktor yang mempengaruhi struktur modal dan hubungannya terhadap nilai perusahaan. Jurnal Manajemen dan Bisnis. 7(4). 82-99.

Modigliani, F., dan Miller, M. H. 1958. The cost of capital, corporate finance, and theory of investment. American Economic Review. 48. 261-297.

Modigliani, F., dan Miller, M. H. 1963. Corporate income taxes and the cost of capital: a correction. The American economic review, 53(3), 433-443.
Myers, Stewart C. 1984. The capital structure puzzle. Journal of Finance. 39(3). 575 -592 .

Myers, S. C., dan Majluf, N. S. 1984. Corporate financing and investment decisions when firms have information that investors do not have. Journal of Financial Economics. 13(2). 187-221

Maxwell, O., dan Kehinde, F. 2012. Capital structure and firm value: empirical evidence from Nigeria. International Journal of Business and Social Science3 (19).

Priyono, A. A. 2010, Faktor-faktor yang mempengaruhi struktur modal pada perusahaan manufaktur yang terdaftar di BEI. Working Paper. Unisma.

Sabir, M. dan Malik, Q.A. 2012. Determinants of capital structure - a study of oil and gas sector of Pakistan.Interdisciplinary Journal Of Contemporary Research In Business. 3(10).

Sartono, A. 2001.Manajemen Keuangan: Teori dan Aplikasi, Edisi 4.Yogyakarta: Penerbit BPFE.

Stefani dan Handayani R. 2011. Faktor-faktor yang mempengaruhi struktur modal pada perusahaan publik sektor manufaktur. Jurnal Bisnis dan Akuntansi, 13(1), 81-96.

Utami, Endang Sri. 2009.Faktor-faktor yang mempengaruhi struktur modal perusahaan manufaktur.Fenomena, 7(1), $39-47$.

Weston, J. F. dan Copeland, T. E. 1986. Managerial Finance, $9^{\text {th }}$ edition.Tokyo: The Dryden Press Company. 